\section{Auge azucarero, mortalidad y políticas \\ de salud en San Miguel de Tucumán \\ en la segunda mitad del siglo XIX}

María Paula Parolo
Daniel Campi
María Estela Fernández

María Paula Parolo es Investigadora Asistente del CONI-

CET y Profesora de la Universidad Nacional de Tucumán. e-mail: pparolo@herrera.unt.edu.ar

Daniel Campi es Investigador del CONICET y Profesor de la Universidad Nacional de Tucumán.

e-mail: dcampi@ct.unt.edu.ar

María Estela Fernández es Profesora de la Universidad

Nacional de Tucumán.

e-mail: marielaf@arnet.com.ar

\section{Resumen}

Hasta el presente las referencias sobre los efectos sociales del auge azucarero tucumano de las últimas décadas del siglo XIX, se limitan a relatos realizados sobre la base de diversas y desiguales descripciones de época. Una vía para acceder con más rigor a la problemática es el análisis de la mortalidad a partir de los registros de defunciones de la parroquia La Victoria, cuya jurisdicción comprendía parte del tejido urbano de de San Miguel de Tucumán y parte de la campaña circundante, el área de mayor concentración de plantíos cañeros e ingenios azucareros en la época. En este contexto, este artículo pretende reconstruir con tales registros la curva de mortalidad entre 1859 y 1892 , detectar los picos de defunciones, identificar sus causas y trazar la evolución del perfil epidemiológico con el objeto de aproximarnos a un indicador social clave para un segmento de la población tucumana con gran concentración de trabajadores azucareros, indagando, asimismo, sobre las políticas públicas referidas a la salud de la población.
Una primera versión de este artículo fue presentada en las XX Jornadas de Historia Económica, Mar del Plata, octubre de 2006. Los autores agradecen los comentarios de Adriana Álvarez, María Beatriz Ceballos y Raquel Gil Montero. La investigación fue realizada en el marco de proyectos financiados por el Consejo de Investigaciones de la Universidad Nacional de Tucumán y por la Agencia Nacional de Promoción Científica y Tecnológica.

\section{Summary}

Until present, references about the social effects of the Tucumán sugar boom in the last decades of the 19th century are restricted to the various erratic descriptions of the time. One way to have a more rigorous access to the issue is to analyze mortality rates according to the death certificates from "La Victoria» parish, whose jurisdiction involved part of the urban area of San Miguel de Tucumán and some countryside surrounding. Both were the area with most sugar cane plantations and mills of that time. In this context, the present article aims to reconstruct the mortality curve between 1859 and 1892, in order to detect death peaks, to identify their causes and trace an evolution of the epidemiological profile. Starting from these indicators, the present work aims to approach to a key social indicator for a segment of Tucumán's population with a high concentration of sugarcane workers. The paper also inquires about health-related public policies. 